hereditary orotic aciduria is not difficult in principle, using small amounts of a palatable soluble chemical given by mouth and free of side-effects. Observation of the peripheral blood should be sufficient to control dosage, supplemented when necessary by bone-marrow examinations and estimations of orotic acid excretion. Through the generosity of Nutritional Biochemicals Corp., Cleveland, Ohio, uridine is at present supplied at a cost which is reasonable in comparison with that of treating many chronic diseases. The treatment of orotic aciduria detected in early infancy promises to be simple, economic, and rewarding.

\section{Summary}

A second case of hereditary orotic aciduria is described. This diagnosis was established in a 17-month-old boy with megaloblastic anaemia who failed to respond to treatment with vitamin $\mathrm{B}_{12}$, folic acid, pyridoxine, and thyroxine. He was found to excrete more than $1 \mathrm{~g}$. of orotic acid daily.

Preliminary results of biochemical studies support the previous hypothesis that this is an inborn error of pyrimidine metabolism in which there is marked reduction in activity of two sequential enzymes in the major pathway of pyrimidine synthesis. This is transmitted as an autosomal recessive trait.

Haematological remission was induced by the nucleoside uridine and has been maintained for 18 months. Previous physical and mental retardation has responded to treatment, although some degree of intellectual impairment is likely to persist. The likelihood of gratifying results from early diagnosis and treatment of this disease is emphasized.

We should like to thank Dr. G. T. Fox, senior paediatrician, for permission to publish this case. We are indebted to Dr. Charles $M$. Huguley, jun., and Dr. Lloyd H. Smith, jun., for advice on the management of the case ; to Drs. Huguley, Smith, and Robert S. Krooth for permission to include preliminary results of their investigations; to Dr. F. H. Sims, Dr. R. K. Ralph, and Miss Anne Simmonds for chemical investigations; to Dr. J. M. Staveley, haematologist, Auckland Hospital, for opinions on bone-marrow specimens; to Dr. D. M. G. Beasley, paediatrician, Whangarei Hospital, for information on the early course of the patient; to Dr. J. M. Costello and Miss M. Blackwell for psychometric assessments ; and to Sister H. J. Smyth for nursing care.

\section{REFERENCES}

Carter, C. E. (1956). Ann. Rev. Biochem., 25, 123 .
Elves, M. W., Buttoo, A. S., Israels, M. C. G., and Wilkinson, J. F. (1963). Brit. med. F., 1, 156.

Fallon, H. J., Lotz, M., and Smith, L. H., jun. (1962). Blood, 20, 700. Smith, L. H., jun., Graham, J. B., and Burnett, C. H. (1964). New Engl. ₹. Med., 270, 878.

Hepple, L. A., and Rabinowitz, J. C. (1958). Ann. Rev. Biochem., 27, 613.

Huguley, C. M., jun., and Bain, J. A. (1960). In The Metabolic Basis of Inherited Disease, edited by J. B. Stanbury, J. B. Wyngaarden, and D. S. Fredrickson, p. 776. McGraw-Hill, New York.

Rivers, S. L., and Scoggins, R. B. (1959). Blood, 14, 615.

Jacob, F., and Monod, J. (1961). 7. molec. Biol, 3, 318.

Krooth, R. S., Howell, R. R., and Hamilton, H. B. (1962). F. exp. Med., 115,313 .

and Weinberg, A. N. (1961). Ibid., 113, 1155.

Lotz, M., Fallon, H. J., and Smith, L. H., jun. (1963). Nature (Lond.), 197, 194.

Monod, J., Changeux, J. P., and Jacob, F. (1963). F. molec. Biol., 6,

Smith, C. H. (1960). Blood Diseases of Infancy and Childhood. Mosby, St. Louis.

Smith, L. H., jun., and Baker, F. A. (1959). 7. clin. Invest., 38, 798. - Huguley, C. M., jun., and Bain, J. A. (1964). In The Metabolic

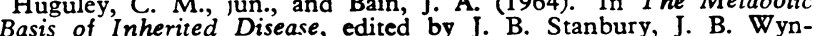
Basis of Inherited Disease, edited by gaarden, and D. S. Fredrickson, 2nd ed. McGraw-Hil

Sullivan, M., and Huguley, C. M., jun. (1961). F. clin. Invest., 40, 656.

Weissman, S. M., Eisen, A. Z., Fallon, H., Lewis, M., and Karon, M. (1962). Ibid., 41, 1546 .

Yates, R. A., and Pardee, A. B. (1956). F. biol. Chem., 221, 757.

\title{
Hypocholesterolaemia and Orotic Aciduria During Treatment with 6-Azauridine
}

\author{
A. S. BUTTOO,* M.D. ; M. C. G. ISRAËLS,* M.D., M.SC., F.R.C.P. ; \\ JOHN F. WILKINSON,* M.D., M.SC., PH.D., F.R.C.P., F.R.I.C.
}

Brit. med. F., 1965, 1, 552-554

The pyrimidine analogue 6-azauridine (6-AzUR) has been used in the experimental treatment of leukaemia (Wilkinson, 1963, 1964). It is a moderately potent antileukaemic drug, free from serious toxicity, which exhibits some unusual and interesting side-effects. The urinary excretion of large quantities of orotidine and orotic acid demonstrates the drug's interference with the de novo synthesis of pyrimidine nucleotides (Handschumacher et al., 1960a), which is also reflected in the chromosomal changes seen in the leucocytes of leukaemic patients treated with 6-AzUR (Elves et al., 1963). Another effect, noted by Fallon et al. (1961), is an increased uric-acid clearance.

6-AzUR therapy may result in the appearance of megaloblastic changes in the marrow, presumably due to inhibition of orotidylic decarboxylase. An increased plasma clearance of intravenously injected folic acid and urinary excretion of formiminoglutamic acid following a histidine load have also

* Department of Clinical Haematology, University and Royal Infirmary, Manchester. been noted (unpublished observation). We are reporting hcre a hitherto undescribed side-effect of 6-AzUR therapynamely, the depression of serum-cholesterol levels.

This finding was noticed during the performance of liverfunction tests to exclude hepatotoxicity of 6-AzUR. The importance of this finding lies in the fact that 6-AzUR is perhaps the only substance available at the present moment that appears capable of affecting both the nucleic acid and the lipid metabolisms. Besides affording exciting possibilities for future investigations, this property of 6-AzUR has a potential value in the lowering of the plasma-cholesterol level in clinical medicine. Apart from hypocholesterolaemia, 6-AzUR did not induce any other abnormality in the liver-function tests.

\section{Methods}

Clinical Studies.-Five patients with various types of acute leukaemia, one patient with lymphosarcoma, and another with multiple myeloma were each given $10 \mathrm{~g}$. daily of $6-\mathrm{AzUR}$ by a 
continuous intravenous drip for a period of two to three weeks in each instance (see Table I), while Case 5 was given orally $7.5 \mathrm{~g}$. of triacetyl-AzUR daily in three equally divided doses. No concurrent treatment with any other antileukaemic drug was given during this period, but fresh blood was transfused whenever it was thought necessary. All patients received the ordinary hospital diet. Serum-cholesterol levels were determined before, during, and after treatment with 6-AzUR. The daily urinary excretion of orotidine and orotic acid was estimated in all patients.

Experimental Studies.-Sprague Dawley rats of both sexes, aged $3 \frac{1}{2}$ to 4 months, were divided into two groups (control and test). Rats in the test group were given, orally, $500 \mathrm{mg}$. of triacetyl-AzUR per kg. body weight. After four and after eleven days of treatment five rats of each sex, together with five control rats of each sex, were killed and blood was removed by cardiac puncture for serum-cholesterol estimation.

Analytical Procedures.-Total serum cholesterol was estimated by the method of Sackett (1925). Addition of 6-AzUR to serum in vitro did not interfere with the sterol determination.

The daily urinary excretion of orotidine and orotic acid in the leukaemic patients was estimated by ultra-violet spectrophotometry, after separation by ion-exchange chromatography. The method used was that of Handschumacher as modified by Fallon et al. (1961).

\section{Results}

The clinical and laboratory studies of the eight patients in the present series yielded results which are summarized in Table I. There was a pronounced fall in the serum-cholesterol levels in four patients (Cases 2, 4, 5, and 8) during 6-AzUR therapy. The serum-cholesterol concentration returned to pretreatment levels two weeks after cessation of the therapy. The fall of cholesterol concentrations in Cases 1, 3, 6, and 7, determined within the first four days of the start of therapy, was not statistically significant.

The results of the chromatographic fractionation of patients' urine is shown in Table II. The urinary excretion of orotic acid and orotidine fluctuated from day to day: the former reached a peak on the second or third day and then slowly declined during the remainder of the treatment period, whereas the latter reached a maximum a little later, while sustaining somewhat higher levels throughout the therapy. Fig. 1 illustrates the typical excretion pattern of orotic acid and orotidine as found in Case 6.

The effect of 6-AzUR on the serum cholesterol in young rats after oral treatment with $500 \mathrm{mg}$. of triacetyl-AzUR per kg. body weight gave the results shown in Table III. Acetylation of the free hydroxyl groups of the ribose converts 6-AzUR into the lipid-soluble triacetate. This compound, after absorption from the small intestine, is hydrolysed in the bloodstream to free 6-AzUR (Handschumacher et al., 1962). The effect on orotic acid and orotidine excretion (Case 5, Table II) is similar to that of the non-acetylated compound, thus suggesting that the response of rats to the triacetate is comparable.

Table III shows that no effect was discernible on the serumcholesterol concentrations after four days' treatment, but by the eleventh day of treatment there was a significant lowering of serum cholesterol in both sexes.

TABLE II.-Urinary Excretion of Orotidine and Orotic Acid in Leukaemic

\begin{tabular}{|c|c|c|c|c|c|}
\hline \multicolumn{6}{|c|}{ Palients } \\
\hline $\begin{array}{l}\text { Case } \\
\text { No. }\end{array}$ & $\begin{array}{c}\text { Duration } \\
\text { of } \\
\text { Therapy } \\
\text { (days) }\end{array}$ & $\begin{array}{c}\text { Total } \\
\text { Orotidine } \\
\text { (g.) }\end{array}$ & $\begin{array}{c}\text { Total } \\
\text { Orotic } \\
\text { Acid } \\
\text { (g.) }\end{array}$ & $\begin{array}{l}\text { Average } \\
\text { Orotidine } \\
\text { (g./24 hr.) }\end{array}$ & $\begin{array}{c}\text { Average } \\
\text { Orotic } \\
\text { Acid } \\
\text { (g./24 hr.) }\end{array}$ \\
\hline $\begin{array}{l}1 \\
2 \\
3 \\
4 \\
5 \\
6 \\
7 \\
8\end{array}$ & $\begin{array}{l}22 \\
4 \\
18 \\
17 \\
17 \\
17 \\
15 \\
20\end{array}$ & $\begin{array}{l}50 \cdot 41 \\
8.95 \\
47.89 \\
40.78 \\
43.85 \\
38.96 \\
25.34 \\
54 \cdot 72\end{array}$ & $\begin{array}{l}57 \cdot 26 \\
10.55 \\
45.11 \\
41.73 \\
36.06 \\
30.84 \\
31.32 \\
47.99\end{array}$ & $\begin{array}{l}2 \cdot 29 \\
2 \cdot 24 \\
2.52 \\
2 \cdot 26 \\
2.44 \\
2.29 \\
1.69 \\
2 \cdot 61\end{array}$ & $\begin{array}{l}2.73 \\
2.64 \\
2.51 \\
2 \cdot 32 \\
2.12 \\
1.81 \\
2 \cdot 24 \\
2.40\end{array}$ \\
\hline
\end{tabular}

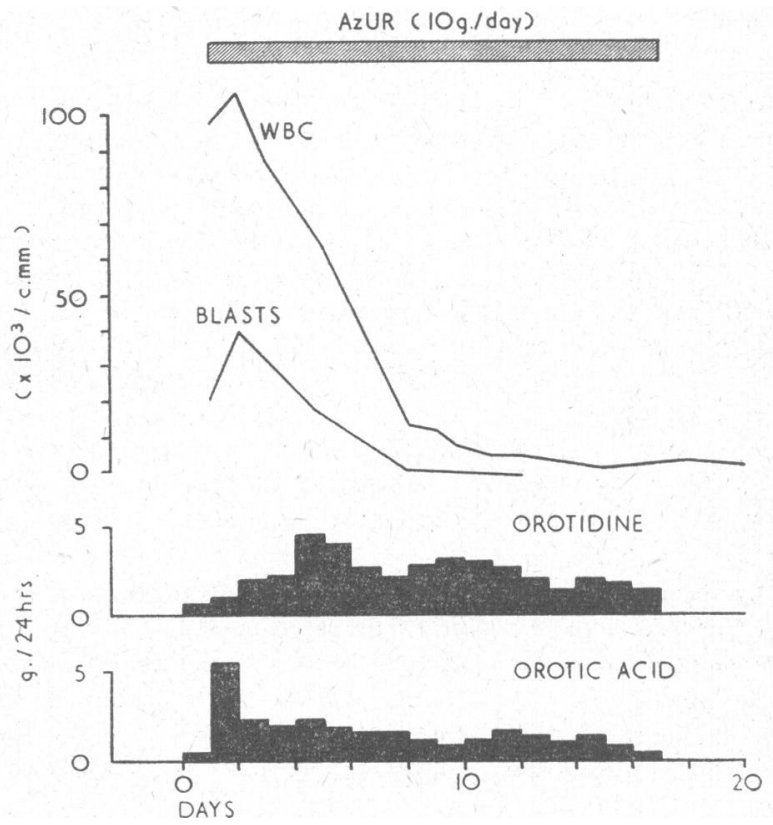

FIG. 1.-Leucocytes and urinary excretion of pyrimidine compounds during AzUR therapy in Case 6.

TABLE III.-Serum Cholesterol of Rats After 4 and 11 Days' Treatment (mg./100 ml.)

\begin{tabular}{|c|c|c|c|c|}
\hline \multirow{2}{*}{ Sex } & \multicolumn{2}{|c|}{4 Days } & \multicolumn{2}{|c|}{11 Days } \\
\hline & Test & Control & Test & Control \\
\hline$M$ & $\begin{array}{c}56 \pm 1 \cdot 15\left(\begin{array}{c}(55-57) \\
\text { Not sig }\end{array}\right.\end{array}$ & $\begin{array}{l}56 \pm 6 \cdot 27(46-61) \\
\text { nificant }\end{array}$ & $\begin{array}{c}20 \pm 5.22(12-25) \\
0.02>P\end{array}$ & $\begin{array}{l}48 \pm 18 \cdot 30(31-75) \\
>0 \cdot 01\end{array}$ \\
\hline F & $63 \pm 10 \cdot 16\left(\begin{array}{c}50-73) \\
0 \cdot 4>\end{array}\right.$ & $\begin{array}{l}54 \pm 13.89(38-75) \\
?>0.3\end{array}$ & $25 \pm 9 \cdot 37\left(\begin{array}{c}(14-37) \\
0.02>\end{array}\right.$ & $\begin{array}{l}41 \pm 5.83(36-51) \\
P>0.01\end{array}$ \\
\hline
\end{tabular}

\section{Discussion}

6-AzUR is a pyrimidine analogue which interferes with the de novo synthesis of pyrimidine nucleotides and coenzymes. In the body it is phosphorylated by means of uridine kinase to 6-azauridine-5'-phosphate. This compound competitively inhibits decarboxylation of orotidylic acid, thus leading to

TABle I.-Changes in White-cell Count and Cholesterol in Patients Receiving 6-AzUR

\begin{tabular}{|c|c|c|c|c|c|c|c|c|c|c|c|c|c|}
\hline \multirow{2}{*}{$\begin{array}{l}\text { Case } \\
\text { No. }\end{array}$} & \multirow{2}{*}{$\begin{array}{c}\text { Sex and } \\
\text { Age }\end{array}$} & \multirow{2}{*}{\multicolumn{5}{|c|}{ Diagnosis }} & \multicolumn{2}{|c|}{ Initial Count per c.mm. } & \multicolumn{2}{|c|}{ Lowest Count per c.mm. } & \multicolumn{3}{|c|}{ Serum Cholesterol (mg./100 ml.) } \\
\hline & & & & & & & w.B.c. & Blasts & w.B.c. & Blasts & $\begin{array}{c}\text { Pre- } \\
\text { treatment }\end{array}$ & $\underset{\text { Treatment* }}{\text { During }}$ & $\begin{array}{c}\text { Post- } \\
\text { treatment }\end{array}$ \\
\hline $\begin{array}{l}1 \\
2 \\
3 \\
4 \\
5 \\
6 \\
7 \\
8\end{array}$ & $\begin{array}{ll}M & 25 \\
M & 51 \\
M & 60 \\
M & 31 \\
M & 30 \\
M & 47 \\
M & 57 \\
M & 54\end{array}$ & $\begin{array}{l}\text { Lymphoblastic leukaemia } \\
\text { Myeloblastic leukaemia } \\
\text { ", }, . . . \\
\text { " } \\
\text { Monocytic leukaemia } \\
\text { Lymphosarcoma } \\
\text { Multiple myeloma }\end{array}$ & $\begin{array}{l}\because \\
\because \\
\because \\
\because \\
\therefore\end{array}$ & $\begin{array}{l}\because \\
\because \\
\because \\
\because \\
\ddot{ }\end{array}$ & $\begin{array}{l}\because \\
\because \\
\because \\
\because\end{array}$ & $\begin{array}{l}\because \\
\because \\
\because \\
\because \\
\because\end{array}$ & $\begin{array}{r}47,000 \\
37,200 \\
3,700 \\
60,000 \\
15,300 \\
99,000 \\
7,400 \\
2,700\end{array}$ & $\begin{array}{r}20,210 \\
22,320 \\
2,146 \\
49,000 \\
8,956 \\
10,890 \\
888 \\
-\end{array}$ & $\begin{array}{r}350 \\
30,000 \\
900 \\
22,000 \\
12,000 \\
2,800 \\
5,800 \\
2,300\end{array}$ & $\begin{array}{r}760 \\
243 \\
18,000 \\
2,400 \\
74 \\
145 \\
-\end{array}$ & $\begin{array}{l}230 \\
285 \\
205 \\
295 \\
270 \\
225 \\
240 \\
230\end{array}$ & $\begin{array}{l}200 \\
150 \\
180 \\
100 \\
100 \\
185 \\
200 \\
200 \\
110 \\
110 \\
(10) \\
(10)\end{array}$ & $\begin{array}{l}\frac{250}{240} \\
\frac{260}{200} \\
280\end{array}$ \\
\hline
\end{tabular}

- Day of treatment on which cholesterol was determined is given in parentheses. 
accumulation of orotidine and orotic acid with increased excretion of these compounds in the urine (see Fig. 2).

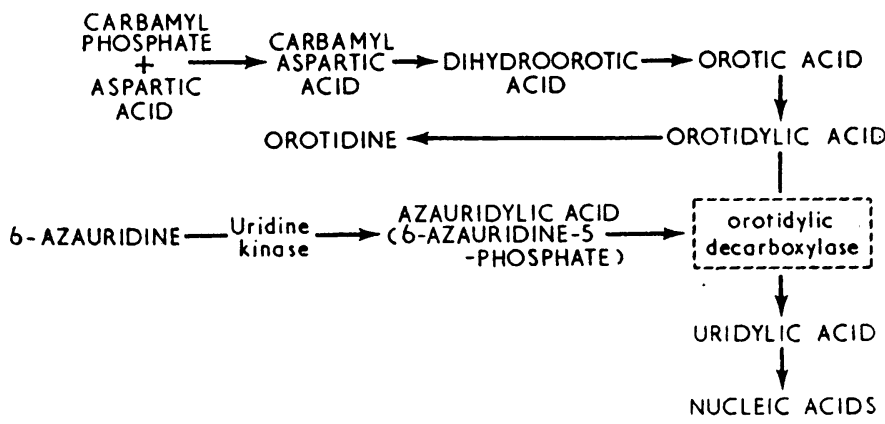

FIG. 2.-Pathways of de novo synthesis of pyrimidine nucleotides and its inhibition by 6-AzUR.

The hypocholesterolaemic effect of 6-AzUR has not previously been reported. However, Standerfer and Handler (1955) showed that the addition of 0.2 to $1 \%$ of orotic acid to the diet produced fatty livers in rats. Addition of uracil or thymine to the orotic-acid diet had no effect. Handschumacher et al. (1960b) found that the administration of adenine restored the liver lipid to normal. Rajalakshmi et al. (1961) confirmed this observation and demonstrated a depression of serum cholesterol concomitant with an accumulation of the sterol and triglyceride in the liver when $1 \%$ orotic acid was added to the diet. From estimations of ${ }^{14} \mathrm{C}$-acetate incorporation into cholesterol they concluded that depression of serum cholesterol was due to decreased synthesis in the liver and mobilization from extrahepatic tissues.

The reversal by adenine of cholesterol accumulation in the liver was ascribed to repair of an adenine deficiency resulting from accelerated nucleic-acid synthesis, itself due to the massaction effect of the expanded pyrimidine pool.

In the light of these reports it seems likely that the hypocholesterolaemia observed in four patients and in the rats treated with 6-AzUR is due to the accumulation in the body of orotic acid or one of its metabolites. It is doubtful, however, whether an excessive synthesis of nucleic acid and a consequent adenine deficiency can be invoked as a cause of the disturbance in lipid metabolism, since 6-AzUR blocks pyrimidine and hence nucleic-acid synthesis. The uricosuric effect of both orotic acid and 6-AzUR reported by Fallon et al. (1961) may be more relevant in this connexion, the excessive excretion of uric acid possibly leading to accelerated oxidation of adenine. The precise mechanism whereby 6-AzUR, orotic acid, or a metabolite influences serum and liver lipids remains unknown.

\section{Summary}

Administration of pyrimidine analogues, 6-AzUR and triacetyl-AzUR, to leukaemic patients resulted in the lowering of serum-cholesterol levels and the urinary excretion of large quantities of orotidine and orotic acid. This hypocholesterolaemia was also noted in rats given triacetyl-AzUR orally. The reason for this effect is not known.

We are grateful to Dr. N. J. Green, of Dista Products (Liverpool) Ltd., for his help with experimental studies on rats.

\section{REFERENCES}

Elves, M. W., Buttoo, A. S., Israëls, M. C. G., and Wilkinson, J. F. (1963). Brit. med. f., 1, 156.

Fallon, H. J., Frei, E., III, Block, J., and Seegmiller, J. E. (1961). J.

clin. Invest., 40, 1906.
Handschumacher, R. E., Calabresi, P., Welch, A. D., Bono, V., Fallon, H., and Frei, E., III (1962). Cancer Chemother. Rep., 21, 1.

Cardoso, S., Jaffe, J. J., Liebow, A. A., Calabresi, P., Finch, S. C., and Welch, A. D. (1960a). Proc. Amer. Ass. Cancer Res., 3, 116. Creasey, W. A. Jaffe, J. J., Pasternack, C. A., and Hankin, I (1960b). Proc. nat. Acad. Sci. (Wash.), 46, 178.

Rajalashi, S. Sarma, D. S. R., and Sarma, P. S. (1961). Biochem. f., 80, 375 .

Sackett, G. E. (1925). 7. biol. Chem., 64, 203.

Standerfer, S. B., and Handler, P. (1955). Proc. Soc. exp. Biol. (N.Y.), $90,270$.

Wilkinson, J. F. (1963). Proc. roy. Soc. Med., 56, 644.

(1964). Practitioner, 193, 470.

\title{
Bacteriuria, Prematurity, and the Hypertensive Disorders of Pregnancy
}

\author{
K. L. STUART,* M.D., M.R.C.P., F.R.C.P.ED., D.T.M. ; G. T. M. CUMMINS, $\dagger$ M.B., M.R.C.o.G. ; \\ W. A. CHIN, $\ddagger$ M.B., B.S.
}

Brıt. med. F., 1965, 1, 554-556

It is well known that clinical pyelonephritis is a relatively common occurrence in pregnancy. Recently attention has been drawn to the high prevalence of asymptomatic bacteriuria in pregnant women (Kass, 1959). In spite of the not uncommon occurrence of eclampsia and pre-eclamptic toxaemia during pregnancy, and in spite of the well-known association of clinical pyelonephritis with hypertension, little knowledge exists of any association between symptomatic or asymptomatic infection of the urinary tract and the hypertensive disorders of pregnancy.

In this study we have established prevalence rates for bacteriuria in pregnant women attending our antenatal clinics. We have followed these subjects to term and compared the occurrence of premature delivery and the rate of emergence of

\footnotetext{
- Reader in Medicine, University of the West Indies. + Medical Registrar, University College Hospital, Jamaica.
}

pre-eclamptic toxaemia or other hypertensive disorders of pregnancy in bacteriuric and non-bacteriuric subjects.

\section{Materials and Methods}

Clean voided specimens of urine were collected at their first hospital visit from 2,713 consecutive pregnant women attending the antenatal clinics of the University College Hospital in Jamaica during the two-year period starting December 1961. Each urine specimen was screened initially on eosin-methyleneblue (E.M.B.) agar. Quantitative bacterial counts were carried out on urines which showed growth on this media and the counts were repeated in subjects with counts of 100,000 or more per ml. of urine. Two or more consecutive counts at this level were regarded as indicative of significant bacteriuria as defined 